Graphical Abstract

\title{
Synthesis, antiplasmodial activity and mechanistic studies of pyrimidine-5- carbonitrile and quinoline hybrids
}

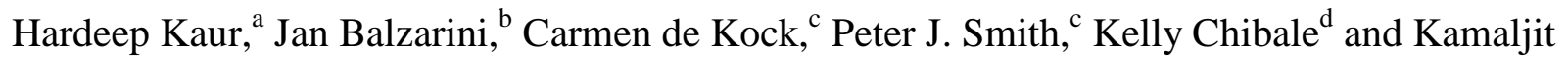
Singh*,a

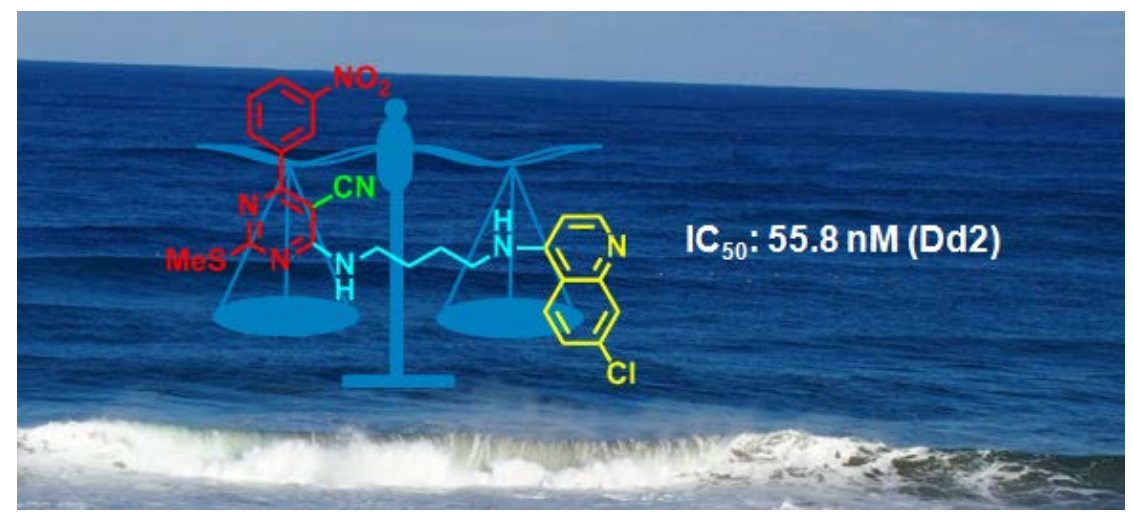

Pyrimidine-quinoline hybrids bearing a cyano group at the 5-position of the pyrimidine ring showed significant antiplasmodial activity, which is influenced by the nature as well as length of the linker linking the two pharmacophores. 


\section{Synthesis, antiplasmodial activity and mechanistic studies of pyrimidine-5- carbonitrile and quinoline hybrids}

Hardeep Kaur, ${ }^{\text {a }}$ Jan Balzarini, ${ }^{\mathrm{b}}$ Carmen de Kock, ${ }^{\mathrm{c}}$ Peter J. Smith, ${ }^{\mathrm{c}}$ Kelly Chibale ${ }^{\mathrm{d}}$ and Kamaljit Singh*,a

${ }^{a}$ Department of Chemistry, UGC-Centre of Advance Study-1,Guru Nanak Dev University, Amritsar-143005, India.

(Tel: +91 183 2258802-09 extn 3508; E-mail: kamaljit.chem@gndu.ac.in; Fax: +91 183 2258819-20)

${ }^{b}$ Rega Institute for Medical Research, KU Leuven, 10 Minderbroedersstraat, B-3000 Leuven, Belgium

${ }^{c}$ Division of Pharmacology, Department of Medicine, University of Cape Town, Observatory 7925, South Africa

${ }^{d}$ Department of Chemistry, South African Medical Research Council Drug Discovery and Development Research Unit, Institute of Infectious Disease and Molecular Medicine, University of Cape Town, Rondebosch 7701, South Africa

Abstract: A series of hybrids comprising of 5-cyanopyrimidine and quinoline moiety were synthesized and tested for in vitro antiplasmodial activity against NF54 and Dd2 strains of Plasmodium falciparum. Hybrid bearing m-nitrophenyl substituent at C-4 of pyrimidine displayed the highest antiplasmodial activity $\left[\mathrm{IC}_{50}=56 \mathrm{nM}\right]$ against the $\mathrm{CQ}^{\mathrm{R}}(\mathrm{Dd} 2)$ strain, which is four-fold greater than CQ.

Keywords- Antiplasmodial agents; 4-Aminoquinoline; Heme binding; Cytotoxic activity; Pyrimidine; Hybrid antimalarials.

\section{Introduction}

Malaria is one of the major causes of morbidity and mortality around the globe and is caused by protozoa of the genus Plasmodium of which $P$. falciparum is the most lethal and widespread species. A recent report of the $\mathrm{WHO}^{1}$ indicated over 190 million cases of malaria and approximately 5,84,000?? deaths in 2013. The emerging resistance to the existing antiplasmodial 
drugs, $^{2}$ absence of new antiplasmodial drugs ${ }^{3}$ and the slow pace of the development of clinically approved vaccines ${ }^{4}$ further compromise the efficient control of this disease. With no licensed malaria vaccines currently in hand, several vaccine projects are in clinical trials, and of these, the most advanced vaccine (RTS, S/AS01) has been evaluated in a Phase 3 clinical trial and is active only against Plasmodium falciparum. The situation is further exacerbated by the decreased clinical efficacy of front-line artemisinin combination therapies (ACTs) currently used for the treatment of malaria. ${ }^{5}$ These factors exemplify the need to discover new, effective, and affordable antiplasmodial chemotherapeutic agents acting through novel mechanisms.

Substituted quinolines are historically ${ }^{6}$ among the most important antiplasmodial agents and their vast use in the $20^{\text {th }}$ century provided well founded hopes for the eradication of malaria. The most important drugs of this family include chloroquine (CQ, 1), quinine, mefloquine, amodiaquine, piperaquine and primaquine (Figure 1). CQ and related 4-aminoquinolines are believed to inhibit the formation of crystalline hemozoin from free ferriprotoporphyrin IX, which is generated during proteolysis of host hemoglobin in the acidic food vacuole (FV) and is toxic to the parasite. ${ }^{6,7}$ However, the extensive use of CQ for the treatment of P. falciparum malaria led to the development of resistance, which is linked to the mutations in the FV membrane protein Pfcrt (P. falciparum chloroquine resistance transporter), which might result in reduced accumulation of CQ in chloroquine-resistant strains. ${ }^{8,9}$

Insert here Figure 1.

To overcome CQ-resistance by P. falciparum, a hybridization approach has proven to be a promising tool as the hybrid drugs act through different mechanisms against either a single or multiple targets and lead to acceptable pharmacological and safety profiles. ${ }^{10}$ In the design of hybrid drugs, the 4-aminoquinoline nucleus has received increasing attention owing to their low cost and good activity-toxicity profiles. Pyrimidines being one of the essential cell constituents represent one of the most important heterocycles that exhibit remarkable pharmacological activities. ${ }^{11}$ Pyrimidines bearing a nitrile war head were reported to display excellent inhibitory activity against both falcipain-2 as well as cultured $P$. falciparum. ${ }^{12}$ The nitrile groups are known to exert antiplasmodial effect by forming a reversible thioimidate intermediate with cysteine residues of cysteine proteases, which ultimately results in the inhibition of the enzyme. ${ }^{13-15}$ 
In our previous reports on pyrimidine-quinoline hybrids ${ }^{16}$, we demonstrated high (nM) antiplasmodial activity of this class of hybrids against both chloroquine-sensitive $\left(\mathrm{CQ}^{\mathrm{S}}\right)$ and chloroquine-resistant $\left(\mathrm{CQ}^{\mathrm{R}}\right)$ strains of $P$. falciparum, which in some cases was even greater than CQ. As an extension of our research interest in this class of hybrids, we herein report on the synthesis and antiplasmodial activity of novel pyrimidine-quinoline hybrids bearing a cyano group at the C-5 position of the pyrimidine, which is covalently linked to the quinoline ring through different linkers. Further, we also report on the efficacy of these hybrids to bind heme as well as $\mu$-oxo heme in order to understand the possible mode of action of these hybrids.

\section{Chemistry}

Pyrimidine-quinoline hybrids reported in this work were prepared using the synthetic protocol outlined in Scheme 1. The substituted pyrimidin-6(1H)-ones 10 were prepared by using a modified Biginelli condensation reaction of ethyl cyanoacetate 7, appropriately substituted benzaldehyde $\mathbf{8}$ and S-methylisothiourea hemisulphate salt 9a/N-morpholinyl guanidine hydrochloride $\mathbf{9 b}$, in ethanol in the presence of $\mathrm{K}_{2} \mathrm{CO}_{3} \cdot{ }^{17}$ Further, treatment of appropriate 10 with excess $\mathrm{POCl}_{3}$ afforded the corresponding 6-chloropyrimidine derivatives 11, in quantitative yields. The nucleophilic displacement reaction of $\mathbf{1 1}$ with 7-chloro-4-aminoquinoline ${ }^{18} \mathbf{1 2}$ in dry THF yielded corresponding hybrids 13 in 82-92\% (Table 1) after column chromatographic purification. The structures of all the hybrids were established on the basis of spectral $\left({ }^{1} \mathrm{H} \mathrm{NMR}\right.$, ${ }^{13} \mathrm{C}$ NMR, EIMS, FTIR) as well as microanalytical data (vide experimental). The structure of 13d was additionally confirmed by single crystal x-ray analysis (Table S1). The ortep diagram of 13d is shown in Figure 2.

Insert here Figure 2.

Insert here Scheme 1.

Insert here Table 1.

\section{Results and discussion}

3.1 In vitro antiplasmodial activity and structure-activity relationships (SARs)

The hybrids 13a-l were evaluated for their activity against $\mathrm{CQ}^{\mathrm{S}}(\mathrm{NF} 54)$ and $\mathrm{CQ}^{\mathrm{R}}$ (Dd2) strains of $P$. falciparum using CQ and artesunate (ASN) reference drugs. The concentrations inhibiting $50 \%$ of parasite growth $\left(\mathrm{IC}_{50}\right)$ were obtained using a non-linear dose-response curve 
fitting analysis via Graph Pad Prism v. 4.0 software (Table 1). Analysis of the antiplasmodial activity data revealed that most of the hybrids (except 13d and 13g) showed significant (nM) activity against $\mathrm{CQ}^{\mathrm{S}}$ [43.8-197.9 nM (NF54)] as well as $\mathrm{CQ}^{\mathrm{R}}$ strains [55.8-1529.7 nM (Dd2)] of $P$. falciparum. Among all the hybrids assayed, hybrid 13e depicted the highest antiplasmodial activity $\left[\mathrm{IC}_{50}=55.8 \mathrm{nM}(\mathrm{Dd} 2)\right]$ against the $\mathrm{CQ}^{\mathrm{R}}$ strain, which is four-fold greater than $\mathrm{CQ}\left[\mathrm{IC}_{50}\right.$ $=257.6 \mathrm{nM}(\mathrm{Dd} 2)]$. Comparison of antiplasmodial activity of the homologues 13a $\left[\mathrm{IC}_{50}=133.7\right.$ nM (NF54); 319.4 nM (Dd2)] and 13b [IC I0 $_{10} 108.6$ nM (NF54); 295.2 nM (Dd2)] showed that a four-methylene spacer confers superior antiplasmodial activity compared to a three-methylene spacer. Further, the replacement of the flexible aliphatic linker of 13a-c with a piperazinyl linker in 13d, led to a complete loss of activity. It is possibly due to the steric restrictions conferred by the piperazinyl linker (Figure 2b) in 13d, which may restrict face-to-face stacking of the quinoline unit with heme, ${ }^{19}$ leading to inefficient inhibition of the heme polymerization to hemozoin. This fact is experimentally supported by titration of monomeric heme with 13d. Gradual addition of 0-37.3 $\mu \mathrm{M}$ of 13d (Figure S1-S2) to a solution of monomeric heme $(2.4 \mu \mathrm{M}$, DMSO: $\mathrm{H}_{2} \mathrm{O} / 4: 6$, v/v) revealed no change in the absorbance at $402 \mathrm{~nm}$ indicating lack of a binding interaction.

Similarly, replacement of the diaminopropyl linker with a less basic aminopropoxy linker in 13c caused a marginal increase in the antiplasmodial activity against both the tested $P$. falciparum strains. This is in contrast to our earlier finding, ${ }^{16 c}$ where a similar change of the linker led to significant loss in antiplasmodial activity. However, in addition to the nature of the linker, the antiplasmodial activity of the current series of pyrimidine-quinoline hybrids seems to be benefitted by the presence of a cyano group on the pyrimidine unit, which are known to inhibit cysteine proteases ${ }^{13-15}$ and show antiplasmodial effects.

Comparison of the antiplasmodial activity of the hybrids 13b, 13e, 13f, $13 \mathbf{h}$ and $13 \mathbf{k}$ suggested that 13e $\left[\mathrm{IC}_{50}=68.5 \mathrm{nM}\left(\mathrm{NF} 54, \mathrm{CQ}^{\mathrm{S}}\right) ; 55.8 \mathrm{nM}\left(\mathrm{Dd} 2, \mathrm{CQ}^{\mathrm{R}}\right)\right]$ bearing a $m$-nitro substituent at the C-4 phenyl ring showed highest activity against both the $P$. falciparum strains. Moreover, position of the nitro substituent on the aromatic ring also significantly modulated (Table 1) the antiplasmodial activity. Thus, the $m-\mathrm{NO}_{2}$ substituted analogue [13e: $\mathrm{IC}_{50}=68.5 \mathrm{nM}$ (NF54); $55.8 \mathrm{nM}(\mathrm{Dd} 2)]$ showed superior activity against $\mathrm{CQ}^{\mathrm{R}}$ strain, while, a $p-\mathrm{NO}_{2}$ [13f: $\mathrm{IC}_{50}$ $=43.8 \mathrm{nM}$ (NF54); $531.6 \mathrm{nM}(\mathrm{Dd} 2)$ ] substituted derivate was more active against $\mathrm{CQ}^{\mathrm{S}}$ strain. In 
the case of methoxy substituted hybrids $(\mathbf{1 3 h}-\mathbf{j})$, all the hybrids depicted good antiplasmodial activity against the $\mathrm{CQ}^{\mathrm{S}}$ strain and mild activity against $\mathrm{CQ}^{\mathrm{R}}$ strain, except the 3,4,5trimethoxyphenyl substituted hybrid 13j $\left[\mathrm{IC}_{50}=90.9\right.$ nM (NF54); 89.9 nM (Dd2)], which exhibited 3-fold greater antiplasmodial activity than CQ [ $\left.\mathrm{IC}_{50}=257.6 \mathrm{nM}(\mathrm{Dd} 2)\right]$ against $\mathrm{CQ}^{\mathrm{R}}$ strain and is the second most potent $\left[\mathrm{IC}_{50}=90.9 \mathrm{nM}\right.$ (NF54); $89.9 \mathrm{nM}$ (Dd2)] hybrid of the current series of compounds. Furthermore, replacement of the C-2 S-methyl group of the pyrimidine unit in 13b [ $\mathrm{IC}_{50}=197.9 \mathrm{nM}$ (NF54); $385.8 \mathrm{nM}$ (Dd2)] by morpholine ring to yield hybrid 13I [ $\mathrm{IC}_{50}=108.6 \mathrm{nM}$ (NF54); $295.2 \mathrm{nM}$ (Dd2)] led to a deterioration of antiplasmodial activity against both $\mathrm{CQ}^{\mathrm{S}}$ as well as $\mathrm{CQ}^{\mathrm{R}}$ strains. The molecular weight of these hybrids is close to 500 and $\operatorname{CLog} P$ values are in the range 5-7.51 (Table 1). While the selectivity indices (SI) of these hybrids are low, the most active hybrids $\mathbf{1 3} \mathbf{e}(\mathrm{RI}=0.81)$ and $\mathbf{1 3} \mathbf{j}(\mathrm{RI}=0.98)$ depicted good resistance index, which is better than the standard antiplasmodial drugs (CQ \& ASN, Table 1).

This brief SAR study on the new pyrimidine-quinoline hybrids clearly demonstrated that the antiplasmodial activity of these hybrids was significantly influenced by the cyano group at C-5 position, type and length of the methylene spacer linking pyrimidine and quinoline units as well as the substitution pattern (C-2 as well as C-4 positions) of the pyrimidine unit.

\subsection{Cytotoxicity}

Cytotoxicity of 13a-l and reference CQ was evaluated using murine leukemia cells (L1210), human T-lymphocyte cells (CEM) and human cervix carcinoma cells (HeLa). The cytotoxicity data revealed that most of these hybrids except 13d and $\mathbf{1 3 g}$ were more cytotoxic than CQ against all the three tested mammalian tumor cell lines (Table 2). Moreover, the SI of all the hybrids [1.9-103.7 $\left(\mathrm{CQ}^{\mathrm{S}}\right)$; 1.1- 44.0 $\left(\mathrm{CQ}^{\mathrm{R}}\right)$ ] is lower than CQ [SI = $972.9\left(\mathrm{CQ}^{\mathrm{S}}\right)$; $69.8\left(\mathrm{CQ}^{\mathrm{R}}\right)$ ]. However, the SI of the most active hybrids $\mathbf{1 3 e}$ and $\mathbf{1 3} \mathbf{j}$, against $\mathrm{CQ}^{\mathrm{R}}$ strain was higher (Table 2) and approached that of CQ. Thus, these hybrids display cytotoxicity (Table 2) only at concentrations that are significantly higher than concentrations at which hybrids displayed antiplasmodial activity.

Insert here Table 2.

\subsection{Antiviral activity}


Antiplasmodial drugs such as CQ, artemisinin, and quinine inhibit several RNA and DNA viruses. ${ }^{20} \mathrm{CQ}$ being a weak lysosomotropic base exerts antiviral activity by inhibiting replication of some viruses either through reducing the efficiency of endosome-mediated virus entry or through inhibiting the low-pH-dependent proteases in trans-Golgi vesicles. ${ }^{21-22}$ Taking into consideration the antiviral activity of CQ, we evaluated antiviral activity of hybrids 13a-I against several viruses such as (i) herpes simplex virus-1 (KOS), herpes simplex virus-2 (G), vaccinia virus, vesicular stomatitis virus, herpes simplex virus-1 (TK'KOS ACV ${ }^{\mathrm{r}}$ ) and adenovirus using HEL cell cultures (ii) vesicular stomatitis virus, coxsackie virus B4, respiratory syncytial virus in HeLa cell cultures, (iii) parainfluenza-3 virus, reovirus-1, Sindbis virus, Coxsackie virus B4, Punta Toro virus in Vero cell cultures, (iv) cytomegalovirus using AD-169 and Davis strain in HEL cell cultures, (v) varicella-zoster virus (VZV) in HEL cell cultures (Table S2-S3) and (vi) influenza A virus (H1N1 and H3N2) and influenza B virus in MDCK cell cultures, (Table S2S3). The data showed that none of the hybrids display any antiviral activity at subtoxic concentrations (Table S2-S3).

\subsection{Possible mode of antiplasmodial effects}

Malarial parasite invades the host red blood cells and feed on the hemoglobin. The released heme byproduct Fe(III)-protoporphyrin IX, is toxic to the parasite, and is sequestered into physiologically insoluble hemozoin crystals (heme detoxification). ${ }^{6}$ Quinoline drugs form $\pi-\pi$ complex with heme ferriprotoporphyrin IX (FPPIX) in FV, and inhibit the formation of hemozoin crystals. ${ }^{6-7}$ This inhibition of heme crystallization leads to the accumulation of heme in FV thereby causing parasite death. Thus, quinoline drugs exert antimalarial effect by inhibiting the heme detoxification process. In order to get an insight into the possible mode of action of these hybrids we decided to evaluate the binding of the most potent hybrid 13e (Table 1) of the current series with monomeric as well as dimeric heme using UV-visible absorption spectrophotometery. ${ }^{16}$

The titrations were performed at $\mathrm{pH} 7.4$ as well as 5.6 representing the acidic $\mathrm{pH}$ of the food vacuole. The sequential addition of 13e [pH 7.4: 0-18.3 $\mu \mathrm{M}$; $\mathrm{pH}$ 5.6: 0-52.5 $\mu \mathrm{M}$ (DMSO)] to a solution of monomeric heme in 0.02 M HEPES buffer in aqueous DMSO representing a constant concentration $(2.4 \mu \mathrm{M})$ showed a substantial decrease in the absorption intensity of the Soret band of Fe(III)PPIX at $402 \mathrm{~nm}$ without significant shift in the position of the absorption band 
(Figure 3A-4A). This significant hypochromism indicated complexation between Fe(III)PPIX and quinolone unit of 13e. Further, the Job’s plot revealed 1:1 stoichiometry of the most stable complex of 13e with monomeric heme at $\mathrm{pH} 7.5$ and 5.6 (Figure 3B-4B).

Insert here Figure 3.

To ascertain the formation of the proposed complex, mass spectrum of the complex obtained by mixing equimolar solutions of hemin chloride $(0.24 \mathrm{mM})$ and 13e $(0.24 \mathrm{mM})$ was recorded. The spectrum depicted an intense molecular ion peak at $\mathrm{m} / \mathrm{z} 1135.4094$ (Figure 5), corresponding to the molecular formula $\mathrm{C}_{59} \mathrm{H}_{54} \mathrm{ClFeN}_{11} \mathrm{O}_{6} \mathrm{~S}$ of the $1: 1$ complex.

Further, it is known that CQ binds to heme dimer ( $\mu$-oxo heme) ${ }^{23}$ and thus the binding assay was extended to $\mu$-oxo heme also. Titration of $\mu$-oxo heme (10 $\mu \mathrm{M}, 0.02 \mathrm{M}$ phosphate buffer) with sequential addition of $13 \mathbf{e}(0-13.7 \mu \mathrm{M})$ at $\mathrm{pH} 5.8$ showed a decrease in the intensity of the broad peak at $364 \mathrm{~nm}$ (Figure 6A). Further, the Job’s plot calculations indicated a 1:1 stoichiometry for the most stable complex of $\mu$-oxo heme and 13e (Figure 6B). A similar titration of CQ with heme was also performed under identical conditions, and the association constants were compared (Table 3).

Insert here Figure 4.

Insert here Figure 5.

The association constants (Table 3) were calculated from the titration data obtained for monomeric heme (at pH 7.4 and 5.6) and $\mu$-oxo heme using HypSpec, a nonlinear least-squares fitting program. ${ }^{24}$ The greater association constants of $\mathbf{1 3 e}$ with both monomeric $(\mathrm{pH} 7.4$ and $\mathrm{pH}$ 5.6) as well as $\mu$-oxo heme compared to CQ (Table 3) suggested stronger complexation of 13e with heme. Furthermore, the observed trend of the binding of the hybrid with heme (Table 3) suggested stronger binding at the lower $\mathrm{pH}$. The comparison of association constants of 13e for monomeric and $\mu$-oxo heme revealed that the hybrid has greater affinity for the $\mu$-oxo heme and thus, possibly inhibits hemozoin formation by blocking the growing face of heme leading to the observed antiplasmodial activity. The calculated association constants of $\mathbf{1 3 e}$ are quite comparable with the hybrids $^{16}$ lacking a C-5 carbonitrile, this suggested that the primary mechanism of action of these hybrids is through inhibition of heme polymerization, although the cysteine protease inhibition might be playing a supportive role.

Insert here Figure 6. 
Insert here Table 3.

\section{Conclusions}

Covalently linked hybrids of pyrimidine-5-carbonitrile and 4-aminoquinoline display structure-dependent antiplasmodial activity in nM range, which is superior to the corresponding hybrids lacking the 5-cyano group on the pyrimidine unit. The hybrids possessing a nitrophenyl group at the C-4 position and a SMe group at the C-2 position of the pyrimidine unit are more effective against both CQ-sensitive and CQ-resistant strains. The hybrids 13e and 13j displayed the highest antiplasmodial activity against the $\mathrm{Dd} 2\left(\mathrm{CQ}^{\mathrm{R}}\right)$ strain. However, the current design of hybrids gave a lower selectivity index compared to CQ. From the heme binding studies, it is concluded that inhibition of hemozoin formation is the primary mechanism of antiplasmodial activity of this class of hybrids, while the cyano substitution seems to play a positive but a supportive role.

\section{$5 \quad$ Experimental}

\subsection{General information}

All liquid reagents were dried/purified following recommended drying agents and/or distilled over $4 \AA$ molecular sieves. THF was dried (Na- benzophenone ketyl) under nitrogen. ${ }^{1} \mathrm{H}$ NMR (300 MHz, $400 \mathrm{MHz}$ and $500 \mathrm{MHz}),{ }^{13} \mathrm{C}(75 \mathrm{MHz}, 100 \mathrm{MHz}$ and $125 \mathrm{MHz}$ ), were recorded in $\mathrm{CDCl}_{3}$ and DMSO- $d_{6}$ on a multinuclear Jeol FT-AL-300 spectrometer and BrukerAvance II 400 \& III 500 spectrometer with chemical shifts being reported in parts per million $(\delta)$ relative to internal tetramethylsilane (TMS, $\delta 0.0,{ }^{1} \mathrm{H}$ NMR) or chloroform $\left(\mathrm{CDCl}_{3}, \delta\right.$ 77.0, ${ }^{13} \mathrm{C}$ NMR). Mass spectra were recorded on a Bruker LC-MS MICROTOF II spectrometer. Elemental analysis was performed on FLASH EA 112 (Thermo electron Corporation) analyzer and the results are quoted in \%. IR spectra were recorded on Perkin Elmer FTIR-C92035 Fourier transform spectrometer in the range 400-4000 $\mathrm{cm}^{-1}$ using $\mathrm{KBr}$ pellets. For monitoring the progress of a reaction and for comparison purpose, thin layer chromatography (TLC) was performed on pre-coated aluminum sheets of Merck $\left(60 \mathrm{~F}_{254}, 0.2 \mathrm{~mm}\right)$ using an appropriate solvent system. The chromatograms were visualized under UV light. For column chromatography silica gel (60-120 mesh) was employed and eluents were ethyl acetate/hexane or ethyl acetate/methanol mixtures. The $\mathrm{pH}$ measurements were performed with the Equip-Tronics Digital pH meter model-EQ 610. The purities of all the final compounds were confirmed to be $\geq$ 
95\% by combustion methods. UV-visible spectral studies were conducted on Shimadzu 1601 PC spectrophotometer with a quartz cuvette (path length, $1 \mathrm{~cm}$ ). The absorption spectra have been recorded between 1100 and $200 \mathrm{~nm}$. The cell holder of the spectrophotometer was thermostatted at $25^{\circ} \mathrm{C}$ for consistency in the recordings.

\subsection{Synthesis of pyrimidin-6(1H)-ones (10a-h)}

5.2.1 Synthesis of 5-cyano-2-methylthio-4-phenylpyrimidin-6(1H)-one (10a)

In a typical procedure, to a solution of $S$-methylisothiourea $(1 \mathrm{~g}, 11.10 \mathrm{mmol})$, benzaldehyde ( $2.23 \mathrm{ml}, 22.10 \mathrm{mmol})$, and ethyl cyanoacetate $(2.37 \mathrm{ml}, 22.10 \mathrm{mmol})$ in ethanol (40 ml), $\mathrm{K}_{2} \mathrm{CO}_{3}\left(3.06 \mathrm{~g}, 22.10 \mathrm{mmol}\right.$ ) was added. The reaction mixture was heated to $80^{\circ} \mathrm{C}$ for 5 $\mathrm{h}$ and filtered after cooling to isolate the corresponding product. Recrystallization from methanol provided 10a as yellow crystalline solids in $84 \%$ yield. Rf: 0.75 (ethyl acetate). m.p. $>250{ }^{\circ} \mathrm{C}$ (methanol). IR (KBr): $v_{\max }$ 1469, 1563, 1656, 2195, 3061, $3234 \mathrm{~cm}^{-1} .{ }^{1} \mathrm{H}$ NMR $(500 \mathrm{MHz}$, DMSO- $d_{6}, 25{ }^{\circ} \mathrm{C}$ ): $\delta 2.35$ (s, 3H, $\mathrm{SCH}_{3}$ ), 7.45-7.47 (m, 3H, ArH), 7.75 (t, $\left.2 \mathrm{H}, J 5.8 \mathrm{~Hz}, \mathrm{ArH}\right)$. ${ }^{13} \mathrm{C}$ NMR (125 MHz, DMSO- $\left.d_{6}, 25{ }^{\circ} \mathrm{C}\right): \delta 13.7,89.0,120.7,126.6,127.4,128.5,129.2,130.0$, 138.1, 167.3, 170.9 and 172.9. Anal. Calcd. for $\mathrm{C}_{12} \mathrm{H}_{9} \mathrm{~N}_{3} \mathrm{OS}$ : C, 59.26; $\mathrm{H}, 3.70 ; \mathrm{N}, 17.28, \mathrm{~S}$, 13.18. Found: C, 59.31; H, 3.80; N, 17.19, S, 13.30. EIMS: m/z $244(\mathrm{M}+\mathrm{H})^{+}$. UV/vis (DMSO): $\lambda_{\max }\left(\varepsilon / \mathrm{L} \mathrm{mol}^{-1} \mathrm{~cm}^{-1}\right) 328 \mathrm{~nm}(57900)$.

Following the above procedure and using appropriate aldehyde, 10b-g were analogously prepared. For the preparation of $\mathbf{1 0 h}$, condensation of benzaldehyde, ethyl cyanoacetate and $\mathrm{N}$ morpholinyl guanidine hydrochloride was performed. The experimental details as well as characteristic data of $\mathbf{1 0 b}-\mathbf{h}$ are presented in the supplementary data.

\subsection{Synthesis of 4-aryl-5-cyano-6-chloro-2-methylthiopyrimidines (11a-h)}

\subsubsection{Synthesis of 5-cyano-6-chloro-2-(methylthio)-4-phenylpyrimidine (11a)}

A suspension of 10a $(0.50 \mathrm{~g}, 2.05 \mathrm{mmol})$ in distilled $\mathrm{POCl}_{3}(5 \mathrm{ml}, 53.80 \mathrm{mmol})$ was heated at $105{ }^{\circ} \mathrm{C}$ for $3 \mathrm{~h}$ and the excess $\mathrm{POCl}_{3}$ was removed under reduced pressure. The residue was purified by column chromatography (60-120 mesh silica) using ethyl acetate/hexane as chromatograpic eluent $(1: 9 \mathrm{v} / \mathrm{v})$ to obtain the product as white solid in 97\% yield. Rf: 0.74 [ethyl acetate:hexane/1:4 $(v / v)$ ]. m.p. $110{ }^{\circ} \mathrm{C}$ (dichloromethane/hexane). IR (KBr): $v_{\max } 1474,1537$, 
2228, $3066 \mathrm{~cm}^{-1} .{ }^{1} \mathrm{H}$ NMR (500 MHz, $\left.\mathrm{CDCl}_{3}, 25{ }^{\circ} \mathrm{C}\right): \delta 2.66\left(\mathrm{~s}, 3 \mathrm{H}, \mathrm{SCH}_{3}\right), 7.52-7.54(\mathrm{~m}, 3 \mathrm{H}$, ArH), 8.03 (d, 2H, J 10.0 Hz, ArH). ${ }^{13} \mathrm{C}$ NMR (125 MHz, $\mathrm{CDCl}_{3}, 25{ }^{\circ} \mathrm{C}$ ): $\delta 14.7,100.7,114.6$, 128.5, 128.9, 129.2, 130.1, 132.5, 134.3, 163.5, 168.5, and 176.4. Anal. Calcd. for $\mathrm{C}_{12} \mathrm{H}_{8} \mathrm{ClN}_{3} \mathrm{~S}$ : C, 55.17; H, 3.06; N, 16.09, S, 12.25. Found: C, 55.22; H, 3.11; N, 16.17; S, 12.34. EIMS: m/z $261\left(\mathrm{M}^{+}\right)$. UV/vis $\left(\mathrm{CH}_{2} \mathrm{Cl}_{2}\right): \lambda_{\max }\left(\varepsilon / \mathrm{L} \mathrm{mol}^{-1} \mathrm{~cm}^{-1}\right) 286 \mathrm{~nm}(9160)$.

Following the similar procedures and using appropriate $\mathbf{1 0 b}-\mathbf{h}, \mathbf{1 1 b}-\mathbf{h}$ were analogously prepared. The experimental details as well as characteristic data of $\mathbf{1 0 b}-\mathbf{h}$ are presented in the supplementary data.

5.4 General procedure for the synthesis of pyrimidine-5-carbonitrile-quinoline hybrids

The solution of appropriate 4-aminoquinoline 12 (3.38 mmol) in dry THF (10 ml) was added to the stirred solution of $\mathbf{1 1}(1.69 \mathrm{mmol})$ and potassium carbonate $(8.45 \mathrm{mmol})$ in dry THF $(20 \mathrm{ml})$. The reaction mixture was stirred at room temperature for $48 \mathrm{~h}$ and upon completion (TLC), the reaction mixture was filtered and the filtrate was concentrated under vacuum. The residue was purified by column chromatography over 60-120 mesh silica using hexane/ethyl acetate or ethyl acetate/methanol (13a-l) as eluent. Using this procedure, the following compounds were isolated.

2-Methylthio-4-phenyl-6-[(7-chloroquinolin-4-yl)aminopropyl]aminopyrimidine-5carbonitrile (13a)

Chromatograpic eluent: ethyl acetate/methanol (99:1 v/v). White solid. Rf: 0.40 (ethyl acetate). Yield: 87\%. m.p. 205-207 C (dichloromethane/hexane). IR (KBr): $v_{\max }$ 1583, 2209, 2935, 3343 $\mathrm{cm}^{-1} .{ }^{1} \mathrm{H}$ NMR (300 MHz, $\mathrm{CDCl}_{3}, 25^{\circ} \mathrm{C}$ ): $\delta 2.06$ (t, 2H, $J 6.0 \mathrm{~Hz}, \mathrm{CH}_{2}$ ), $2.58\left(\mathrm{~s}, 3 \mathrm{H}, \mathrm{SCH}_{3}\right), 3.46$ (t, 2H, J $6.0 \mathrm{~Hz}, \mathrm{CH}_{2}$ ), 3.74-3.81 (m, 2H, $\mathrm{CH}_{2}$ ), 5.55 (br, 1H, $\mathrm{D}_{2} \mathrm{O}$ exchangeable, $\mathrm{NH}$ ), 5.87 (br, 1H, D $\mathrm{D}_{2} \mathrm{O}$ exchangeable, NH), 6.44 (d, 1H, J 5.4 Hz, ArH), 7.38 (dd, 1H, J 2.4 Hz, 6.6 Hz, ArH), 7.48-7.52 (m, 3H, ArH), 7.87 (d, 1H, J 9.0 Hz, ArH), 7.95-7.98 (m, 3H, ArH), 8.53 (d, 1H, J 5.1 $\mathrm{Hz}, \mathrm{ArH}) .{ }^{13} \mathrm{C} \mathrm{NMR}\left(75 \mathrm{MHz}, \mathrm{CDCl}_{3}, 25{ }^{\circ} \mathrm{C}\right): \delta 14.0,27.5,42.0,42.2,83.5,99.1,116.8,117.9$, 124.4, 127.8, 128.9, 131.4, 133.8, 136.4, 149.4, 150.4, 152.2, 161.6, 167.3 and 174.4. Anal. Calcd. for $\mathrm{C}_{24} \mathrm{H}_{21} \mathrm{ClN}_{6} \mathrm{~S}$ : C, 62.60; H, 4.56; N, 18.26, S, 6.95. Found: C, 62.41; H, 4.64; N, 18.13; S, 6.88. EIMS: $m / z 461(\mathrm{M}+\mathrm{H})^{+}$. UV/vis $\left(\mathrm{CH}_{2} \mathrm{Cl}_{2}\right): \lambda_{\max }\left(\varepsilon / \mathrm{L} \mathrm{mol}^{-1} \mathrm{~cm}^{-1}\right) 254 \mathrm{~nm}(39198)$, $324 \mathrm{~nm}(15040)$. 
2-Methylthio-4-phenyl-6-[(7-chloroquinolin-4-yl)aminobutyl]aminopyrimidine-5carbonitrile (13b)

Chromatograpic eluent: ethyl acetate/methanol (99:1 v/v). White solid. Rf: 0.50 (ethyl acetate). Yield: 82\%. m.p. 160-162 ${ }^{\circ} \mathrm{C}$ (dichloromethane/hexane). IR (KBr): $v_{\max } 1578,2213,2927,3060$, $3282 \mathrm{~cm}^{-1} .{ }^{1} \mathrm{H}$ NMR (300 MHz, $\mathrm{CDCl}_{3}, 2{ }^{\circ} \mathrm{C}$ ): $\delta$ 1.87-1.92 (m, 4H, $2 \times \mathrm{CH}_{2}$ ), 2.56 (s, 3H, $\mathrm{SCH}_{3}$ ), 3.42-3.45 (m, 2H, $\mathrm{CH}_{2}$ ), 3.60-3.69 (m, 2H, $\mathrm{CH}_{2}$ ), 5.03 (br, $1 \mathrm{H}, \mathrm{D}_{2} \mathrm{O}$ exchangeable, $\mathrm{NH}$ ), 5.74 (br, 1H, $\mathrm{D}_{2} \mathrm{O}$ exchangeable, NH), 6.44 (d, $\left.1 \mathrm{H}, J 5.1 \mathrm{~Hz}, \mathrm{ArH}\right), 7.36$ (d, 1H, J 2.1 Hz, ArH), 7.39-7.53 (m, 3H, ArH), 7.68 (d, 1H, J 9.0 Hz, ArH), 7.95-7.97 (m, 3H, ArH), 8.55 (d, 1H, J 5.4 Hz, ArH). ${ }^{13} \mathrm{C}$ NMR (75 MHz, $\left.\mathrm{CDCl}_{3}, 25{ }^{\circ} \mathrm{C}\right): \delta 14.0,25.5,26.5,41.0,42.5,79.6,83.3,99.1,116.7,117.9$, 124.4, 124.5, 127.9, 128.9, 131.4, 133.8, 136.4, 149.5, 150.5, 152.3, 161.5, 167.3 and 174.4. Anal. Calcd. for $\mathrm{C}_{25} \mathrm{H}_{23} \mathrm{ClN}_{6} \mathrm{~S}$ : C, 63.29; H, 4.85; N, 17.72; S, 6.75. Found: C, 63.14; H, 4.72; $\mathrm{N}, 17.64$; S, 6.67. EIMS: $\mathrm{m} / \mathrm{z} 475(\mathrm{M}+\mathrm{H})^{+}$. UV/vis $\left(\mathrm{CH}_{2} \mathrm{Cl}_{2}\right): \lambda_{\max }\left(\varepsilon / \mathrm{L} \mathrm{mol}^{-1} \mathrm{~cm}^{-1}\right) 252 \mathrm{~nm}$ (23710), $324 \mathrm{~nm}$ (7210).

2-Methylthio-4-phenyl-6-[(7-chloroquinolin-4-yl)aminopropoxy]pyrimidine-5-carbonitrile (13c) Chromatograpic eluent: ethyl acetate/methanol $(99: 1 \mathrm{v} / \mathrm{v})$. White solid. Rf: 0.50 (ethyl acetate). Yield: 89\%. m.p. 138-140 ${ }^{\circ} \mathrm{C}$ (dichloromethane/hexane). IR (KBr): $v_{\max } 1332,1580,2220,3061$, $3212 \mathrm{~cm}^{-1} .{ }^{1} \mathrm{H}$ NMR (300 MHz, $\mathrm{CDCl}_{3}, 25^{\circ} \mathrm{C}$ ): $\delta$ 2.29-2.33 (m, 2H, CH$)_{2}$ ), 2.62 (s, 3H, SCH ), 3.59-3.62 (m, 2H, $\mathrm{CH}_{2}$ ), 4.72 (t, 2H, J $5.4 \mathrm{~Hz}, \mathrm{CH}_{2}$ ), 5.40 (br, $1 \mathrm{H}, \mathrm{D}_{2} \mathrm{O}$ exchangeable, NH), 6.49 (d, 1H, J $5.1 \mathrm{~Hz}, \mathrm{ArH}$ ), 7.39 (dd, 1H, J $2.1 \mathrm{~Hz}, 9.0 \mathrm{~Hz}, \mathrm{ArH}$ ), 7.42-7.56 (m, 3H, ArH), 7.82 (d, 1H, J 9.0 Hz, ArH), 7.95 (d, 1H, J 1.8 Hz, ArH), 8.06-8.03 (m, 2H, ArH), 8.55 (d, 1H, J $5.7 \mathrm{~Hz}$, ArH). ${ }^{13} \mathrm{C}$ NMR (75 MHz, $\left.\mathrm{CDCl}_{3}, 25{ }^{\circ} \mathrm{C}\right): \delta 14.4,27.7,40.2,66.5,100.1,115.4,116.3,121.3$, 125.6, 128.8, 128.9, 131.9, 135.2, 148.4, 150.3, 152.6, 165.3, 168.5 and 173.2. Anal. Calcd. for $\mathrm{C}_{24} \mathrm{H}_{20} \mathrm{ClN}_{5} \mathrm{OS}$ : C, 62.47; H, 4.33; N, 15.18; S, 6.94. Found: C, 62.54; H, 4.31; N, 15.11; S, 6.90. EIMS: $m / z 462(\mathrm{M}+\mathrm{H})^{+}$. UV/vis $\left(\mathrm{CH}_{2} \mathrm{Cl}_{2}\right): \lambda_{\max }\left(\varepsilon / \mathrm{L} \mathrm{mol}^{-1} \mathrm{~cm}^{-1}\right) 252 \mathrm{~nm}$ (10780), $312 \mathrm{~nm}$ (3280). 2-Methylthio-4-phenyl-6-[1-(7-chloroquinolin-4-yl]piperazin-4-yl]pyrimidine-5-carbonitrile (13d)

Chromatograpic eluent: ethyl acetate/hexane (80:20 v/v).White solid. Rf: 0.87 (ethyl acetate). Yield: 85\%. m.p. $188-190{ }^{\circ} \mathrm{C}$ (dichloromethane/hexane). IR (KBr): $v_{\max } 1578,2206,2822,2924$, $3035 \mathrm{~cm}^{-1} .{ }^{1} \mathrm{H}$ NMR $\left(300 \mathrm{MHz}, \mathrm{CDCl}_{3}, 25{ }^{\circ} \mathrm{C}\right): \delta 2.59$ (s, $\left.3 \mathrm{H}, \mathrm{SCH}_{3}\right), 3.38(\mathrm{t}, 4 \mathrm{H}, J 4.8 \mathrm{~Hz}$, $2 \times \mathrm{CH}_{2}$ ), 4.27 (t, $4 \mathrm{H}, J 4.8 \mathrm{~Hz}, 2 \times \mathrm{CH}_{2}$ ), 6.88 (d, $\left.1 \mathrm{H}, J 4.8 \mathrm{~Hz}, \mathrm{ArH}\right), 7.46-7.57$ (m, 4H, $\mathrm{ArH}$ ), 
7.89 (dd, 2H, J 1.5 Hz, 6.3 Hz, ArH), 7.98 (d, 1H, J 9.0 Hz, ArH), 8.08 (d, 1H, J $2.1 \mathrm{~Hz}, \operatorname{ArH}$ ), 8.76 (d, 1H, J 4.8 Hz, ArH). ${ }^{13} \mathrm{C}$ NMR (75 MHz, $\left.\mathrm{CDCl}_{3}, 25{ }^{\circ} \mathrm{C}\right): \delta$ 14.4, 47.2, 51.9, 84.1, 109.3, 118.3, 124.7, 126.6, 128.5, 129.0, 129.3, 131.4, 135.2, 136.1, 150.1, 151.9, 156.1, 162.9, 170.8 and 174.5. Anal. Calcd. for $\mathrm{C}_{25} \mathrm{H}_{21} \mathrm{ClN}_{6} \mathrm{~S}$ : C, 63.55; H, 4.44; N, 17.79; S, 6.77. Found: C, 63.61; H, 4.34; N, 17.71; S, 6.70. EIMS: $\mathrm{m} / \mathrm{z} 473(\mathrm{M}+\mathrm{H})^{+}$. UV/vis $\left(\mathrm{CH}_{2} \mathrm{Cl}_{2}\right): \lambda_{\max }\left(\varepsilon / \mathrm{L} \mathrm{mol}^{-1} \mathrm{~cm}^{-1}\right) 252$ $\mathrm{nm}$ (14890), $329 \mathrm{~nm}$ sh (2330).

2-Methylthio-4-(m-nitrophenyl)-6-[(7-chloroquinolin-4-yl)aminobutyl]aminopyrimidine-5carbonitrile (13e)

Chromatograpic eluent: ethyl acetate/hexane (90:10 v/v).Yellow solid. Rf: 0. 34 (ethyl acetate). Yield: 84\%. m.p. $155-157^{\circ} \mathrm{C}$ (dichloromethane/hexane). IR (KBr): $v_{\max } 1347,1583,1725,2202$, 3056, $3360 \mathrm{~cm}^{-1} .{ }^{1} \mathrm{H}$ NMR (300 MHz, $\mathrm{CDCl}_{3}, 25{ }^{\circ} \mathrm{C}$ ): $\delta$ 1.86-1.88 (m, 4H, 2×CH ), 2.69 (s, 3H, $\mathrm{SCH}_{3}$ ), 3.40-3.43 (m, 2H, $\mathrm{CH}_{2}$ ), 3.70-3.72 (m, 2H, $\mathrm{CH}_{2}$ ), 5.01 (br, 1H, $\mathrm{D}_{2} \mathrm{O}$ exchangeable, $\mathrm{NH}$ ), 5.82 (br, 1H, $\mathrm{D}_{2} \mathrm{O}$ exchangeable, NH), 6.44 (d, 1H, J $5.7 \mathrm{~Hz}, \mathrm{ArH}$ ), 7.38 (dd, 1H, J 2.1 Hz, 4.5 Hz, ArH), 7.69 (dd, 1H, J 7.1 Hz, 13.8 Hz, ArH), 7.96 (d, 1H, J 2.1 Hz, ArH), 8.29 (d, 1H, J 7.1 Hz, ArH), 8.38 (d, 2H, J 7.2 Hz, ArH), 8.55 (d, 1H, J 5.4 Hz, ArH), 8.82 (s, 1H, ArH). ${ }^{13} \mathrm{C}$ NMR $\left(75 \mathrm{MHz}, \mathrm{CDCl}_{3}, 25{ }^{\circ} \mathrm{C}\right): \delta 13.6,24.9,25.9,40.5,42.1,83.0,96.9,98.5,115.6,117.3,123.1$, 123.7, 123.8, 125.1, 127.1, 129.8, 133.6, 134.4, 137.4, 147.6, 150.2, 151.3, 160.8, 164.2 and 174.3 . Anal. Calcd. for $\mathrm{C}_{25} \mathrm{H}_{22} \mathrm{ClN}_{7} \mathrm{O}_{2} \mathrm{~S}$ : C, 57.80; H, 4.23; N, 18.88, S, 6.16; Found: C, 57.68; H, 4.23; N, 18.89; S, 6.27;. EIMS: m/z $520(\mathrm{M}+\mathrm{H})^{+}$. UV/vis $\left(\mathrm{CH}_{2} \mathrm{Cl}_{2}\right): \lambda_{\max }\left(\varepsilon / \mathrm{L} \mathrm{mol}^{-1} \mathrm{~cm}^{-1}\right) 252$ nm (15770), $326 \mathrm{~nm}$ (3350).

2-Methylthio-4-(p-nitrophenyl)-6-[(7-chloroquinolin-4-yl)aminobutyl]aminopyrimidine-5carbonitrile (13f)

Chromatograpic eluent: ethyl acetate/hexane (90:10 v/v). Yellow solid. Rf: 0.45 (ethyl acetate). Yield: 88\%. m.p. $150-152{ }^{\circ} \mathrm{C}$ (dichloromethane/hexane). IR (KBr): $v_{\max } 1351,1547,1580,2208$, 2927, 3065, $3335 \mathrm{~cm}^{-1} .{ }^{1} \mathrm{H}$ NMR (300 MHz, $\mathrm{CDCl}_{3}, 25{ }^{\circ} \mathrm{C}$ ): $\delta$ 1.86-1.91 (m, 4H, 2×CH ), 2.57 (s, $3 \mathrm{H}, \mathrm{SCH}_{3}$ ), 3.42-3.44 (m, 2H, $\mathrm{CH}_{2}$ ), 3.71-3.73 (m, 2H, $\left.\mathrm{CH}_{2}\right), 6.43$ (d, 1H, J 5.4 Hz, ArH), 7.37 (dd, 1H, J 2.4 Hz, 9.0 Hz, ArH), 7.68 (d, 1H, J 2.4 Hz, ArH), 7.96 (d, 1H, J 2.1 Hz, ArH), 8.10 (dd, 2H, J 1.8 Hz, 9.0 Hz, ArH), 8.35 (dd, 2H, J 1.8 Hz, 6.0 Hz, ArH), 8.53 (d, 1H, J 5.4 Hz, $\mathrm{ArH}) .{ }^{13} \mathrm{C} \mathrm{NMR}\left(75 \mathrm{MHz}, \mathrm{CDCl}_{3}, 25{ }^{\circ} \mathrm{C}\right): \delta 13.6,24.9,25.9,40.5,42.0,98.3,101.5,117.4$, 123.3, 123.8, 127.1, 129.8, 133.5, 141.8, 148.5, 150.2, 151.3, 160.8 and 174.3. Anal. Calcd. for 
$\mathrm{C}_{25} \mathrm{H}_{22} \mathrm{ClN}_{7} \mathrm{O}_{2} \mathrm{~S}$ : C, 57.80; H, 4.23; N, 18.88, S, 6.16; Found: C, 57.68; H, 4.23; N, 18.89; S 6.27. EIMS: $\mathrm{m} / \mathrm{z} 520(\mathrm{M}+\mathrm{H})^{+}$. UV/vis $\left(\mathrm{CH}_{2} \mathrm{Cl}_{2}\right): \lambda_{\max }\left(\varepsilon / \mathrm{L} \mathrm{mol}^{-1} \mathrm{~cm}^{-1}\right) 252 \mathrm{~nm}(19840), 320 \mathrm{~nm}$ (4630).

2-Methylthio-4-(p-nitrophenyl)-6-[1-(7-chloroquinolin-4-yl]piperazin-4-ylpyrimidine-5carbonitrile (13g)

Chromatograpic eluent: ethyl acetate/hexane (80:20 v/v). White solid. Rf: 0.54 (ethyl acetate). Yield: 91\%. m.p. $190{ }^{\circ} \mathrm{C}$ (dichloromethane/hexane). IR (KBr): v $\max 1423,1533,2210,2923$, $3039 \mathrm{~cm}^{-1} .{ }^{1} \mathrm{H}$ NMR (300 MHz, $\left.\mathrm{CDCl}_{3}, 25{ }^{\circ} \mathrm{C}\right): \delta 2.59\left(\mathrm{~s}, 3 \mathrm{H}, \mathrm{SCH}_{3}\right), 3.50-3.52\left(\mathrm{~m}, 4 \mathrm{H}, 2 \times \mathrm{CH}_{2}\right)$, 4.30-4.33 (m, 4H, 2× $\mathrm{CH}_{2}$ ), 6.92 (d, 1H, J $\left.5.4 \mathrm{~Hz}, \mathrm{ArH}\right), 7.52$ (dd, 1H, J 2.0 Hz, $9.0 \mathrm{~Hz}, \mathrm{ArH}$ ), 7.98-8.07 (m, 3H, ArH), 8.19 (s, 1H, ArH), 8.35 (d, 2H, J 9.0 Hz, ArH), 8.75 (d, 1H, J 5.1 Hz, $\mathrm{ArH}) .{ }^{13} \mathrm{C}$ NMR (75 MHz, $\left.\mathrm{CDCl}_{3}, 25{ }^{\circ} \mathrm{C}\right): \delta 13.5,14.1,29.5,29.7,46.9,51.6,123.4,126.9$, 130.3 and 152.2. Anal. Calcd. for $\mathrm{C}_{25} \mathrm{H}_{20} \mathrm{ClN}_{7} \mathrm{O}_{2} \mathrm{~S}$ : C, 58.02; H, 3.86; N, 18.95; S, 6.19. Found: C, 57.91; H, 4.00; N, 18.90; S, 6.19. EIMS: $m / z 518(\mathrm{M}+\mathrm{H})^{+}$. UV/vis $\left(\mathrm{CH}_{2} \mathrm{Cl}_{2}\right): \lambda_{\max }\left(\varepsilon / \mathrm{L} \mathrm{mol}^{-1}\right.$ $\left.\mathrm{cm}^{-1}\right) 252 \mathrm{~nm}$ (15690), $323 \mathrm{~nm}$ sh (4678).

2-Methylthio-4-(p-methoxylphenyl)-6-[(7-chloroquinolin-4-yl)aminobutyl]aminopyrimidine-5carbonitrile (13h)

Chromatograpic eluent: ethyl acetate/hexane (80:20 v/v). Yellow solid. Rf: 0.46 (ethyl acetate). Yield: 80\%. m.p. $145-147^{\circ} \mathrm{C}$ (dichloromethane/hexane). IR (KBr): $v_{\max } 1050,1259,1566,2210$, 2948, $3309 \mathrm{~cm}^{-1} .{ }^{1} \mathrm{H}$ NMR (300 MHz, $\mathrm{CDCl}_{3}, 25{ }^{\circ} \mathrm{C}$ ): $\delta$ 1.77-1.79 (m, 4H, 2×CH ), 2.48 (s, 3H, $\mathrm{SCH}_{3}$ ), 3.30-3.33 (m, 2H, CH 2 ), 3.60-3.62 (m, 2H, $\mathrm{CH}_{2}$ ), 3.80 (s, 3H, $\mathrm{OCH}_{3}$ ), 5.00 (br, 1H, $\mathrm{D}_{2} \mathrm{O}$ exchangeable, NH), 5.70 (br, 1H, $\mathrm{D}_{2} \mathrm{O}$ exchangeable, NH), 6.36 (d, 1H, J 5.4 Hz, ArH), 6.93 (d, 2H, J 9.0 Hz, ArH), 7.30 (d, 1H, J 7.2 Hz, ArH), 7.60 (d, 1H, J 8.7 Hz, ArH), 7.95-7.89 (m, 3H, $\mathrm{ArH}), 8.47$ (d, 1H, J $5.1 \mathrm{~Hz}, \mathrm{ArH}) .{ }^{13} \mathrm{C} \mathrm{NMR}\left(75 \mathrm{MHz}, \mathrm{CDCl}_{3}, 25{ }^{\circ} \mathrm{C}\right.$ ): $\delta 16.7,28.4,29.4,32.1$, 45.1, 57.9, 101.5, 116.4, 123.3, 127.9, 131.2, 132.9 and 154.4. Anal. Calcd. for $\mathrm{C}_{26} \mathrm{H}_{25} \mathrm{ClN}_{6} \mathrm{OS}$ : C, 61.90; H, 4.96; N, 16.66, S, 6.34. Found: C, 61.74; H, 5.03; N, 16.71; S, 6.43. EIMS: m/z 505 $(\mathrm{M}+\mathrm{H})^{+}$. UV/vis $\left(\mathrm{CH}_{2} \mathrm{Cl}_{2}\right): \lambda_{\max }\left(\varepsilon / \mathrm{L} \mathrm{mol}^{-1} \mathrm{~cm}^{-1}\right) 252 \mathrm{~nm}$ (13940), $310 \mathrm{~nm}$ (7140).

2-Methylthio-4-(3,4-dimethoxylphenyl)-6-[(7-chloroquinolin-4-yl)aminobutyl] aminopyrimidine-5-carbonitrile (13i) 
Chromatograpic eluent: ethyl acetate/hexane (85:15 v/v). Yellow solid. Rf: 0.39 (ethyl acetate). Yield: 85\%. m.p. $108{ }^{\circ} \mathrm{C}$ (dichloromethane/hexane). IR (KBr): $v_{\max }$ 1022, 1262, 1489, 1581, 2202, 2963, $3351 \mathrm{~cm}^{-1} .{ }^{1} \mathrm{H}$ NMR (300 MHz, $\left.\mathrm{CDCl}_{3}, 25{ }^{\circ} \mathrm{C}\right): \delta$ 1.72-1.75 (m, 4H, 2×CH ), 2.45 (s, $\left.3 \mathrm{H}, \mathrm{SCH}_{3}\right), 3.29-3.31\left(\mathrm{~m}, 2 \mathrm{H}, \mathrm{CH}_{2}\right), 3.57-3.59\left(\mathrm{~m}, 2 \mathrm{H}, \mathrm{CH}_{2}\right), 3.84$ (d, 6H, J $3.0 \mathrm{~Hz}$, 2× $\mathrm{OCH}_{3}$ ), 5.05 (br, 1H, $\mathrm{D}_{2} \mathrm{O}$ exchangeable, $\mathrm{NH}$ ), 5.70 (br, 1H, $\mathrm{D}_{2} \mathrm{O}$ exchangeable, $\mathrm{NH}$ ), 6.31 (d, 1H, J 5.4 Hz, ArH), 6.85 (d, 1H, J 8.4 Hz, ArH), 7.26 (t, 1H, J 6.9 Hz, ArH), 7.47 (d, 1H, J 2.1 $\mathrm{Hz}, \mathrm{ArH}), 7.57-7.60$ (m, 2H, ArH), 7.85 (d, 1H, J 2.1 Hz, ArH), 8.41 (d, 1H, J 5.1 Hz, ArH). ${ }^{13} \mathrm{C}$ NMR (75 MHz, $\left.\mathrm{CDCl}_{3}, 25{ }^{\circ} \mathrm{C}\right): \delta 13.1,24.9,26.3,28.6,40.4,44.9,55.0,98.2,110.4,118.1$, 121.3, 127.3, 147.1, 151.3, 160.3, 162.3 and 176.1. Anal. Calcd. for $\mathrm{C}_{27} \mathrm{H}_{27} \mathrm{ClN}_{6} \mathrm{O}_{2} \mathrm{~S}$ : C, 60.67; H, 5.05; N, 15.73, S, 5.99. Found: C, 60.68; H, 5.04; N, 15.62; S, 5.94. EIMS: m/z $535(\mathrm{M}+\mathrm{H})^{+}$. UV/vis $\left(\mathrm{CH}_{2} \mathrm{Cl}_{2}\right): \lambda_{\max }\left(\varepsilon / \mathrm{L} \mathrm{mol}^{-1} \mathrm{~cm}^{-1}\right) 252 \mathrm{~nm}$ (18390), $322 \mathrm{~nm}$ (13280).

2-Methylthio-4-(3,4,5-trimethoxylphenyl)-6-[(7-chloroquinolin-4-yl)aminobutyl] aminopyrimidine-5-carbonitrile (13j)

Chromatograpic eluent: ethyl acetate/hexane (90:10 v/v). Yellow solid. Rf: 0.37 (ethyl acetate). Yield: 83\%. m.p. 100-102 ${ }^{\circ} \mathrm{C}$ (dichloromethane/hexane). IR (KBr): $v_{\max } 1220,1487,1581,2204$, 2934, 3106, $3341 \mathrm{~cm}^{-1} .{ }^{1} \mathrm{H}$ NMR (300 $\mathrm{MHz} \mathrm{CDCl}_{3}, 25{ }^{\circ} \mathrm{C}$ ): $\delta 1.87-1.90\left(\mathrm{~m}, 4 \mathrm{H}, 2 \times \mathrm{CH}_{2}\right), 2.50$ (s, 3H, $\mathrm{SCH}_{3}$ ), 3.40-3.42 (m, 2H, $\mathrm{CH}_{2}$ ), 3.69-3.71 (m, $\left.2 \mathrm{H}, \mathrm{CH}_{2}\right), 3.91$ (s, 9H, 3× $\left.\mathrm{OCH}_{3}\right), 5.88$ (br, $1 \mathrm{H}, \mathrm{D}_{2} \mathrm{O}$ exchangeable, NH), 6.04 (br, 1H, $\mathrm{D}_{2} \mathrm{O}$ exchangeable, $\left.\mathrm{NH}\right), 6.34$ (d, 1H, J 5.7 Hz, ArH), 7.32 (d, 1H, J 2.4 Hz, ArH), 7.35 (d, 1H, J 2.1 Hz, ArH), 7.80 (d, 2H, ArH), 7.92 (d, 1H, J 2.1 $\mathrm{Hz}, \mathrm{ArH}), 8.40$ (d, $1 \mathrm{H}, J 5.7 \mathrm{~Hz}, \mathrm{ArH}) .{ }^{13} \mathrm{C} \mathrm{NMR}\left(75 \mathrm{MHz}, \mathrm{CDCl}_{3}, 25{ }^{\circ} \mathrm{C}\right.$ ): $\delta 14.3,25.7,26.9$, 40.9, 42.9, 56.3, 60.9, 82.8, 98.4, 99.9, 106.1, 116.5, 117.1, 122.3, 125.7, 125.9, 130.9, 136.0, 140.8, 148.9, 151.2, 153.1, 161.9, 166.1, 175.1 and 177.1. Anal. Calcd. for $\mathrm{C}_{28} \mathrm{H}_{29} \mathrm{ClN}_{6} \mathrm{O}_{3} \mathrm{~S}$ : C, 59.57; H, 5.14; N, 14.89, S, 5.67. Found: C, 59.50; H, 5.09; N, 14.80; S, 5.69. EIMS: m/z 565 $(\mathrm{M}+\mathrm{H})^{+} . \mathrm{UV} / \mathrm{vis}\left(\mathrm{CH}_{2} \mathrm{Cl}_{2}\right): \lambda_{\max }\left(\varepsilon / \mathrm{L} \mathrm{mol}^{-1} \mathrm{~cm}^{-1}\right) 252 \mathrm{~nm}$ (16970), $320 \mathrm{~nm}(9340)$.

2-Methylthio-4-(p-methylphenyl)-6-[(7-chloroquinolin-4-yl)aminobutyl]aminopyrimidine-5carbonitrile (13k)

Chromatograpic eluent: ethyl acetate/hexane (90:10 v/v). Yellow solid. Rf: 0.42 (ethyl acetate). Yield: 84\%. m.p. 153-155 ${ }^{\circ} \mathrm{C}$ (dichloromethane/hexane). IR (KBr): $v_{\max }$ 1577, 2203, 2926, 3244 
$\mathrm{cm}^{-1} .{ }^{1} \mathrm{H}$ NMR (300 MHz, $\left.\mathrm{CDCl}_{3}, 25{ }^{\circ} \mathrm{C}\right): \delta 1.81-1.86\left(\mathrm{~m}, 4 \mathrm{H}, 2 \times \mathrm{CH}_{2}\right), 2.43(\mathrm{~d}, 3 \mathrm{H}, J 3.6 \mathrm{~Hz}$, $\mathrm{CH}_{3}$ ), 2.57 (s, 3H, $\mathrm{SCH}_{3}$ ), 3.42-3.44 (m, 2H, $\mathrm{CH}_{2}$ ), 3.66-3.70 (m, 2H, $\mathrm{CH}_{2}$ ), 5.72 (br, $1 \mathrm{H}, \mathrm{D}_{2} \mathrm{O}$ exchangeable, NH), 6.43 (d, 1H, J 5.4 Hz, ArH), 7.68 (d, 1H, J 8.7 Hz, ArH), 7.86-7.89 (m, 5H, ArH), 7.96 (d, 1H, $J 2.1 \mathrm{~Hz}, \mathrm{ArH}), 8.53$ (d, 1H, $J 5.1 \mathrm{~Hz}, \mathrm{ArH}) .{ }^{13} \mathrm{C}$ NMR $\left(75 \mathrm{MHz}, \mathrm{CDCl}_{3}, 25\right.$ $\left.{ }^{\circ} \mathrm{C}\right): \delta 13.6,21.0,24.9,26.1,40.2,42.2,82.4,98.3,116.4,117.4,123.8,127.1,128.3,128.7$, 133.1, 133.5, 140.8, 150.2, 151.3, 161.2 and 173.8. Anal. Calcd. for $\mathrm{C}_{26} \mathrm{H}_{25} \mathrm{ClN}_{6} \mathrm{~S}$ : C, 63.86; $\mathrm{H}$, 5.15; N, 17.18, S, 6.56; Found: C, 63.79; H, 5.09; N, 17.11; S, 6.49. EIMS: m/z $489(\mathrm{M}+\mathrm{H})^{+}$. UV/vis $\left(\mathrm{CH}_{2} \mathrm{Cl}_{2}\right): \lambda_{\max }\left(\varepsilon / \mathrm{L} \mathrm{mol}^{-1} \mathrm{~cm}^{-1}\right) 254 \mathrm{~nm}$ (36200), $329 \mathrm{~nm}$ (12960).

2-(Morpholin-4-yl)-4-phenyl-6-[(7-chloroquinolin-4-yl)aminobutyl]aminopyrimidine-5carbonitrile (13l)

Chromatograpic eluent: ethyl acetate/hexane (90:10 v/v). White solid. Rf: 0.40 (ethyl acetate). Yield: 92\%. m.p. 178-180 ${ }^{\circ} \mathrm{C}$ (dichloromethane/hexane). IR (KBr): $v_{\max } 1443,2204,2965,3340$ $\mathrm{cm}^{-1} .{ }^{1} \mathrm{H}$ NMR (500 MHz, $\mathrm{CDCl}_{3}, 25{ }^{\circ} \mathrm{C}$ ): $\delta 1.80-1.86$ (m, 4H, $2 \times \mathrm{CH}_{2}$ ), 3.40-3.42 (m, $2 \mathrm{H}, \mathrm{CH}_{2}$ ), 3.63-3.65 (m, $\left.2 \mathrm{H}, \mathrm{CH}_{2}\right), 3.74-3.78\left(\mathrm{~m}, 4 \mathrm{H}, 2 \times \mathrm{CH}_{2}\right), 3.88-3.92\left(\mathrm{~m}, 4 \mathrm{H}, 2 \times \mathrm{CH}_{2}\right), 5.02(\mathrm{br}, 1 \mathrm{H}$, $\mathrm{D}_{2} \mathrm{O}$ exchangeable, $\mathrm{NH}$ ), 5.55 (br, $1 \mathrm{H}, \mathrm{D}_{2} \mathrm{O}$ exchangeable, $\mathrm{NH}$ ), 6.44 (d, $1 \mathrm{H}, J 5.1 \mathrm{~Hz}, \mathrm{ArH}$ ), 7.38 (d, 1H, J 7.3 Hz, ArH), 7.49-7.51 (m, 3H, ArH), 7.67 (d, 1H, J 8.9 Hz, ArH), 7.93-7.98 (m, 3H, ArH), 8.55 (d, $1 \mathrm{H}, J 5.7 \mathrm{~Hz}, \mathrm{ArH}) .{ }^{13} \mathrm{C}$ NMR $\left(125 \mathrm{MHz}, \mathrm{CDCl}_{3}, 25{ }^{\circ} \mathrm{C}\right): \delta 26.2,27.0,40.6$, 42.9, 44.2, 66.7, 99.0, 116.9, 118.5, 120.7, 125.5, 128.3, 128.4, 128.5, 128.7, 130.8, 135.0, 137.0, 148.7, 148.9, 149.6, 151.8, 160.4, 163.5 and 168.5. Anal. Calcd. for $\mathrm{C}_{28} \mathrm{H}_{28} \mathrm{ClN}_{7} \mathrm{O}$ : C, 65.49; $\mathrm{H}$, 5.45; N, 19.10; Found: C, 65.41; H, 5.60; N, 19.01. EIMS: $\mathrm{m} / \mathrm{z} 514(\mathrm{M}+\mathrm{H})^{+}$. UV/vis $\left(\mathrm{CH}_{2} \mathrm{Cl}_{2}\right)$ : $\lambda_{\max }\left(\varepsilon / \mathrm{L} \mathrm{mol}^{-1} \mathrm{~cm}^{-1}\right) 252 \mathrm{~nm}(13020), 326 \mathrm{~nm}(3380)$.

\section{Material and Methods for biological activity determination}

6.1 In vitro antimalarial activity assay

The test samples were tested in triplicate on one or two separate occasions against chloroquine sensitive (CQ $\left.{ }^{\mathrm{S}}\right) \mathrm{NF} 54$ and chloroquine-resistant $\left(\mathrm{CQ}^{\mathrm{R}}\right) \mathrm{Dd} 2$ strains of $P$. falciparum. Continuous in vitro cultures of asexual erythrocyte stages of $P$. falciparum were maintained using a modified method of Trager and Jensen. ${ }^{25}$ Quantitative assessment of antiplasmodial 
activity in vitro was determined via the parasite lactate dehydrogenase assay using a modified method described by Makler. ${ }^{26}$

The test samples were prepared to a $20 \mathrm{mg} / \mathrm{ml}$ stock solution in 100\% DMSO. Samples were tested as a suspension. Stock solutions were stored at $-20^{\circ} \mathrm{C}$. Further dilutions were prepared on the day of the experiment. Chloroquine (CQ) and artesunate were used as the reference drugs in all experiments. A full dose-response was performed for all compounds to determine the concentration inhibiting $50 \%$ of parasite growth ( $\mathrm{IC}_{50}$-value). Test samples were tested at a starting concentration of $100 \mu \mathrm{g} / \mathrm{ml}$, which was then serially diluted 2-fold in complete medium to give 10 concentrations; with the lowest concentration being $0.2 \mu \mathrm{g} / \mathrm{ml}$. The same dilution technique was used for all samples. Reference drugs were tested at a starting concentration of $1000 \mathrm{ng} / \mathrm{ml}$. Active samples were tested at a starting concentration of $1000 \mathrm{ng} / \mathrm{ml}$. The highest concentration of solvent to which the parasites were exposed to had no measurable effect on the parasite viability (data not shown). The $\mathrm{IC}_{50}$-values were obtained using a non-linear dose response curve fitting analysis via Graph Pad Prism v.4.0 software.

\subsection{Cytotoxicity and antiviral activity assays}

Cytotoxicity was determined by exposing different concentrations of the samples to murine leukemia cells (L1210) and human T-lymphocyte cells (CEM) and human cervix carcinoma cells (HeLa). ${ }^{16}$ The cytotoxic activity was determined by measuring the 50\% cytotoxic concentration of compound that inhibited tumor cell proliferation by $50 \%$ as measured by a Coulter counter. The antiviral assays were based on inhibition of virus-induced cytopathicity in HEL [herpes simplex virus type 1 (HSV-1), HSV-2 (G), vaccinia virus, and vesicular stomatitis virus], Vero (parainfluenza-3, reovirus-1, Coxsackie B4, and Punta Toro virus), HeLa (vesicular stomatitis virus, Coxsackie virus B4, and respiratory syncytial virus) and MDCK (influenza A (H1N1; H3N2) and B virus) cell cultures. Confluent cell cultures in microtiter 96-well plates were inoculated with 100 cell culture inhibitory dose-50 (CCID 50$)$ of virus ( $1 \mathrm{CCID}_{50}$ being the virus dose to infect $50 \%$ of the cell cultures) in the presence of varying concentrations of the test compounds. Viral cytopathicity was recorded as soon as it reached completion in the control virus-infected cell cultures that were not treated with the test compounds. The cytotoxicity was microscopically determined or examined with the viability staining (MTT) method. 


\section{Acknowledgements}

We gratefully acknowledge financial assistance from CSIR, New Delhi. H.K. thanks CSIR, New Delhi for senior research fellowship (F. No. 09/254 (0195)/2009-EMR-I). The research of JB was supported by the KU Leuven (GOA 15/19 TBD).

\section{References}

1. WHO, World Malaria Report 2014, http:/www.who.int/malaria/publications/ world_malaria_report_2014/en/.

2. D.A. Fidock, Drug discovery: Priming the antimalarial pipeline. Nature 465 (2010) 297-298.

3. E.H. Ekland, D.A. Fidock, In vitro evaluations of antimalarial drugs and their relevance to clinical outcomes. Int. J. Parasitol. 38 (2008) 743-747.

4. M. Wisniewski, D.J. Zak, Achievements and perspectives of research into development of a vaccine against malaria. Wiad. Parazytol. 56 (2010) 133-140.

5. A.M. Dondorp, F. Nosten, P. Yi, D. Das, A.P. Phyo, J. Tarning, K.M. Lwin, F. Ariey, W. Hanpithakpong, S.J. Lee, P. Ringwald, K. Silamut, M. Imwong, K. Chotivanich, P. Lim, T. Herdman, S.S.; An, S. Yeung, P. Singhasivanon, N.P. Day, N. Lindegardh, D. Socheat, N.J. White, Artemisinin resistance in Plasmodium falciparum malaria. N. Engl. J. Med. 361 (2009) 455-467.

6. M. Foley, L. Tilley, Quinoline antimalarials: Mechanisms of action and resistance. Int. J. Parasitol. 27(1997) 231-240.

7. L. Tilley, P. Loria, M. Foley, Chloroquine and other Quinoline Antimalarials. In Antimalarial Chemotherapy: Mechanisms of Action, Resistance, and New Directions in Drug Discovery; Rosenthal, P. J., Ed.; Humana Press: Totowa, NJ, 2001.

8. R.E. Martin, R.V. Marchetti, A.I. Cowan, S.M. Howitt, S. Broer, K. Kirk, Chloroquine transport via the malaria parasite’s chloroquine resistance transporter. Science 325 (2009) 1680-1682.

9. J.F. Trape, A. Tall, N. Diagne, O. Ndiath, A.B. Ly, J. Faye, F.D. -Ba, C. Roucher, C. Bouganali, A. Badiane, F.D. Sarr, C. Mazenot, T. -Balde, A.D. Raoult, P. Druilhe, O.M. Puijalon, C. Rogier, C. Sokhna, Malaria morbidity and pyrethroid resistance after the 
introduction of insecticide-treated bednets and artemisinin-based combination therapies: a longitudinal study. Lancet Infect. Dis. 11 (2011) 925-932.

10. F. Cosledan, L. Fraisse, A. Pellet, F. Guillou, B. Mordmuller, P.G. Kremsner, A. Moreno, D. Mazier, J.-P. Maffrand, B. Meunier, Selection of a trioxaquine as an antimalarial drug candidate. Proc. Natl. Acad. Sci. 105 (2008) 17579-17584.

11. (a) K. Singh, K. Singh, B. Wan, S. Franzblau, K. Chibale, J. Balzarini, Facile transformation of Biginelli pyrimidin-2(1H)-ones to pyrimidines. In vitro evaluation as inhibitors of Mycobacterium tuberculosis and modulators of cytostatic activity. Eur. J. Med. Chem. 46 (2011) 2290-2294. (b) M.B. Deshmukh, S.M. Salunkhe, D.R. Patil, P.V. Anbhule, A novel and efficient one step synthesis of 2-amino-5-cyano-6-hydroxy-4-aryl pyrimidines and their anti-bacterial activity. Eur. J. Med. Chem. 44 (2009) 2651-2654. (c) S. Rostamizadeh, M. Nojavan, R. Aryan, Sadeghian, H.; Davoodnejad, M. A novel and efficient synthesis of pyrazolo [3, 4] pyrimidine derivatives and the study of their antibacterial activity. Chinese Chem. Lett. 24 (2013) 629-632. (d) N.S. Habib, R. Soliman, K. Ismail, A.M. Hassan, M.T. Sarg, Pyrimidines. Part II: Synthesis of novel pyrimidines, 1,2,4-triazolo[4,3-a]pyrimidin-7-ones and pyrimidino[2,1-c][1,2,4]triazin-8-ones for their antimicrobial and anticancer activities. Boll. Chim. Farmac. 142 (2003) 396-405. (e) T.G. Kvaljevic, M. Klika, M. Kvalj, I.M. Kleimer, S. Jurmanovic, A. Milic, J. Padovan, S. Raic-Malic, Synthesis, cytostatic activity and ADME properties of C-5 substituted and Nacyclic pyrimidine derivatives. Bioorg. Med. Chem. Lett. 22 (2012) 308-312. (f) M.M. Mahmoud, A. Ramiz, Wael, E. Sayed, E. Hagag, A.-H. Adel, A. -Rahman, Synthesis and antiviral activity of new substituted pyrimidine glycosides. J. Hetrocycl. Chem. 48 (2011) 1028-1038. (g) L.J. Liu, J.H. Hong, Synthesis and Anti-Hiv Activity of 4'-Modified Cyclopentenyl Pyrimidine C-Nucleosides. Nucleos. Nucleot. Nucl. 28 (2009) 303-314. (h) M.S. Palanki, P.E. Erdman, L.M. Gayo-Fung, G. I. Shevlin, R.W. Sullivan, M. E. Goldman, L.J. Ransone, B.L. Bennett, A.M. Manning, M. J. Suto, Inhibitors of NF-кB and AP-1 Gene Expression: SAR Studies on the Pyrimidine Portion of 2-Chloro-4trifluoromethylpyrimidine-5-[N-(3‘,5‘-bis(trifluoromethyl)phenyl)carboxamide]. J. Med. Chem. 43 (2000) 3995-4004. (i) A. Agarwal, K. Srivastava, S.K. Puri, P.M.S. Chauhan, Synthesis of 2,4,6-trisubstituted pyrimidines as antimalarial agents. Bioorg. Med. Chem. 
13 (2005) 4645-4650. (j) H. Shao, S. Shi, S. Huang, A.J. Hole, A.Y. Abbas, S. Baumli, X. Liu, F. Lam, D.W. Foley, P.M. Fischer, M. Noble, J.A. Endicott, C. Pepper, S. Wang, Substituted 4-(thiazol-5-yl)-2-(phenylamino)pyrimidines are highly active cdk9 inhibitors: synthesis, x-ray crystal structures, structure-activity relationship, and anticancer activities. J. Med. Chem. 56 (2013) 640-659.

12. (a) R. Oliveira, A.S. Newton, R.C. Guedes, D. Miranda, R.K. Amewu, A. Srivastava, J. Gut, P.J. Rosenthal, P.M. O’Neill, S.A. Ward, F. Lopes, R.A. Moreira, An EndoperoxideBased Hybrid Approach to Deliver Falcipain Inhibitors Inside Malaria Parasites. Chem. Med. Chem. 8 (2013) 1528-1536. (b) J.M. Coteron, D. Catterick, J. Castro, M.J. Chaparro, B. Díaz, E. Fernández, S. Ferrer, F.J. Gamo, M. Gordo, J. Gut, L. de Las Heras, J. Legac, M. Marco, J. Miguel, V. Muñoz, E. Porras, J.C. de La Rosa, J.R. Ruiz, E. Sandoval, P. Ventosa, P.J. Rosenthal, J.M. Fiandor, Falcipain inhibitors: optimization studies of the 2-pyrimidine carbonitrile lead series. J. Med. Chem. 53 (2010) 6129-6152.

13. E. Altmann, S.W.C. Jacob, M. Missbach, Novel purine nitrile derived inhibitors of the cysteine protease cathepsin K. J. Med. Chem. 47 (2004) 5833-5836.

14. (a) V. Ehmke, F. Kilchmann, C. Heindl, K. Cui, J. Huang, T. Schirmeister, F. Diederich, Peptidomimetic Nitriles as Selective Inhibitors for the Malarial Cysteine Protease Falcipain-2. Med. Chem. Comm. 2 (2011) 800-804. (b) V. Ehmke, J.E.Q. Quinsaat, P. Rivera-Fuentes, C. Heindl, C. Freymond, M. Rottmann, R. Brun, T. Schirmeister, F. Diederich, Tuning and Predicting Biological Affinity: Aryl Nitriles as Cysteine Protease Inhibitors. Org. Biomol. Chem. 10 (2012) 5764-5768.

15. (a) R. Oliveira, R.C. Guedes, P. Meireles, I.S. Albuquerque, L.M. Goncalves, E. Pires, M. R. Bronze, J. Gut, P. J. Rosenthal, M. Prudencio, R. Moreira, P. M. O’Neill, F. Lopes, Tetraoxane-Pyrimidine Nitrile Hybrids as Dual Stage Antimalarials. J. Med. Chem. 57 (2014) 4916-4923.

16. (a) K. Singh, H. Kaur, K. Chibale, J. Balzarini, S. Little, P. V. Bharatam, 2Aminopyrimidine based 4-aminoquinoline anti-plasmodial agents. Synthesis, biological activity, structure-activity relationship and mode of action studies. Eur. J. Med. Chem., 52 (2012) 82-97. (b) K. Singh, H. Kaur, K. Chibale, J. Balzarini, Synthesis of 4aminoquinoline-pyrimidine hybrids as potent antimalarials and their mode of action 
studies. Eur. J. Med. Chem. 66 (2013) 314-323. (c) K. Singh, H. Kaur, P. Smith, C. de Kock, K. Chibale, J. Balzarini, Quinoline-pyrimidine hybrids: Synthesis, antiplasmodial activity, SAR and mode of action studies J. Med. Chem. 57 (2014) 435-448.

17. (a) S. Moore, H. Jaeschke, G. Kleinau, S. Neumann, S. Costanzi, J. Jiang, J. Childress, B.M. Raaka, A. Colson, R. Paschke, G. Krause, C.J. Thomas, M.C. Gershengorn, Evaluation of small-molecule modulators of the luteinizing hormone/choriogonadotropin and thyroid stimulating hormone receptors: structure-activity relationships and selective binding patterns. J. Med. Chem. 49 (2006) 3888-3896. (b) C.O. Kappe, Recent advances in the Biginelli dihydropyrimidine synthesis. New tricks from an old dog. Acc. Chem. Res. 33 (2000) 879-888.

18. C.C. Musonda, S. Little, V. Yardley, K. Chibale, Application of multicomponent reactions to antimalarial drug discovery. Part 3: Discovery of aminooxazole4aminoquinolines with potent antiplasmodial activity in vitro. Bioorg. Med. Chem. Lett. 17 (2007) 4733-4736.

19. P.B. Madrid, A.P. Liou, J.L.D. Risi, R.K. Guy, Incorporation of an Intramolecular Hydrogen-Bonding Motif in the Side Chain of 4-Aminoquinolines Enhances Activity against Drug-Resistant P. falciparum. J. Med. Chem. 49 (2006) 4535-4543.

20. T. Efferth, M.R. Romero, D.G. Wolf, T. Stamminger, J.J.G. Marin, M. Marschall, The Antiviral Activities of Artemisinin and Artesunate. Clin Infect Dis. 47 (2008) 804-811.

21. E.E. Ooi, J.S.W. Chew, J.P. Loh, R.C.S. Chua, In vitro inhibition of human influenza A virus replication by chloroquine. Virol. J. 3 (2006) 39-41.

22. A. Savirno, J.R. Boelaert, A. Cassone, G. Majori, R. Cauda, Effects of chloroquine on viral infections: an old drug against today's diseases? Lancet Infect Dis 3 (2003) 722-727.

23. (a) A. Dorn, S.R. Vippagunta, H. Matile, C. Jaquet, J.L. Vennerstrom, R.G. Ridley, An assessment of drug-haematin binding as a mechanism for inhibition of haematin polymerisation by quinoline antimalarials. Biochem. Pharmacol. 55 (1998) 727-736. (b) T.J. Egan, Interactions of quinoline antimalarials with hematin in solution. J. Inorg. Biochem. 100 (2006) 916-926. 
24. P. Gans, A. Sabatini, A. Vacca, Investigation of equilibria in solution. Determination of equilibrium constants with the Hyperquad suite of programmes, Talanta 43 (1996) 17391753.

25. W. Trager, J.B. Jensen, Human malaria parasite in continuous culture, Science 193 (1976) 673-675.

26. M.T. Makler, J.M. Ries, J.A. Williams, J.E. Bancroft, R.C. Piper, B.L. Gibbins, D.J. Hinrichs, Parasite lactate dehydrogenase as an assay for Plasmodium falciparum drug sensitivity, Am. J. Trop. Med. Hyg. 48 (1993) 739-741.

\section{$\underline{\text { Captions for Figures }}$}

Figure 1. Quinoline based antimalarial drugs. 
Figure 2. (A) Ortep diagram of 13d showing stereo view of the molecule and the numbering scheme used in the structure analysis (CCDC number: 1019022). (B) View showing orientation of piperazinyl ring w.r.t quinoline ring.

Figure 3. (A) UV-visible absorption changes in the titration of $\mathbf{1 3 e}$ with monomeric heme at $\mathrm{pH}$ 7.4; (B) Job plot of monomeric heme complex formation at $\mathrm{pH} 7.4 . \mathrm{x}=[\mathbf{1 3 e}] /[\mathbf{1 3 e}]+[$ heme $]$ is the mole fraction of the $\mathbf{1 3 e}, A_{0}$ is the absorbance, when $\mathrm{x}=1$ and $\mathrm{A}$ is the absorbance at respective values of $\mathrm{x}$.

Figure 4. (A) UV-visible absorption changes in the titration of $\mathbf{1 3 e}$ with monomeric heme at $\mathrm{pH}$ 5.6; (B) Job plot of monomeric heme complex formation at $\mathrm{pH}$ 5.6. $\mathrm{x}=[\mathbf{1 3 e}] /[\mathbf{1 3 e}]+[$ heme $]$ is the mole fraction of the 13e, $A_{0}$ is the absorbance, when $x=1$ and $A$ is the absorbance at respective values of $\mathrm{x}$.

Figure 5. (A) The solution phase mass spectrum of $\mathbf{1 3 e}(0.24 \mathrm{mmol})$ upon addition of monomeric heme $(0.24 \mathrm{mmol})$ in $40 \%$ aqueous DMSO solution (inset shows zoom between $\mathrm{m} / \mathrm{z} 1000$ and 2500).

Figure 6. (A) UV-visible absorption changes in the titration of 13e with $\mu$-oxo heme at $\mathrm{pH}$ 5.8; (B) Job plot of $\mu$-oxo heme complex formation at $\mathrm{pH} 5.8 \mathrm{x}=[\mathbf{1 3 e}] /[\mathbf{1 3 e}]+[$ heme $]$ is the mole fraction of the 13e, $A_{0}$ is the absorbance, when $\mathrm{x}=1$ and $\mathrm{A}$ is the absorbance at respective values of $\mathrm{x}$.

\section{$\underline{\text { Caption for Scheme }}$}

Scheme 1 . Synthesis of pyrimidine-5-carbonitrile-quinoline hybrids.

\section{$\underline{\text { Captions for Tables }}$}

Table 1. In vitro antiplasmodial activity of 13a-l against $P$. falciparum (CQ $\left.{ }^{\mathrm{S}}\right)$ NF54 strain and $\left(C Q^{\mathrm{R}}\right)$ Dd2 strain for $\mathrm{n}=3$ ( $\mathrm{n}=$ number of replicates). 
Table 2. In vitro cellular toxicity of 13a-I and CQ against murine leukemia cells (L1210), human T-lymphocyte cells (CEM) and human cervix carcinoma cells (HeLa).

Table 3. Binding constants (log $K$ ) of 13e and CQ with heme and $\mu$-oxoheme. 